\title{
Value Consideration of the Construction of Applied Technology University in China
}

\section{- The Perspective of Western Higher Education Development in the Second Half of Twentieth Century}

\author{
Chen Ming \\ Zaozhuang University, Shandong, 277160
}

Keywords: The second half of the twentieth Century; Western higher education; The legitimacy of modern universities; Applied Technology University

\begin{abstract}
Western developed countries entered the stage of popularization of higher education in the 1960s and 1980s. They also experienced the confusion and new value judgment we are facing today. During this period, they constantly tried to reform, in this series of reforms, the western countries have some common points that pay more attention to the development of science and technology, through the reform of higher education to train a group of senior technicians, to the development of high and new technology has contributed greatly. Through studying the reform of applied professional education in western countries during this period, it is found that it is more appropriate to consider the value system of constructing the applied technical university with its own characteristics from the three bases of establishing the legitimacy of Modern University proposed by Burton Clark.
\end{abstract}

\section{Introduction}

The latter half of the 20th century is a critical period for the reform and development of higher education in Western countries. After years of war, the development of society has shown strong stamina, and accordingly new requirements have been put forward for education, especially for higher education. In the United States, Britain, France, Germany and Russia, there have been some more modern reforms and far-reaching reports and bills. In order to improve the level of economic development, they began to attach importance to vocational education, which is somewhat similar to the current situation in China.

\section{Contribution and Confusion}

Since the expansion of enrollment in 1999, Newly-built Local Undergraduate Colleges and universities have stepped onto the historical stage of the development of China's higher education. According to statistics, in 1999, China's general undergraduate enrollment.

In 2008, the number of ordinary undergraduate enrollment in China has reached. Within 10 years, 
the number of undergraduate enrollment has tripled, and China's higher education has entered a stage of popularization.

The increase in the number is bound to bring about qualitative changes, and the gross enrolment rate of less than $15 \%$ of the personnel training and $15 \%-50 \%$ of the personnel training is obviously different. The newly-established undergraduate colleges and universities have solved the problem of equity in education to a certain extent. Higher education has expanded the group of educated people and given the new school-age groups the opportunity to enter higher education institutions for further study. Nowadays, people's cultural level is generally rising, cultural exchanges are more frequent, and various technical means are more advanced. Of course, the increase in the number of universities, the rise in the number of students also brings confusion: First, how to coordinate the relationship between quantity and quality in education? How to ensure the quality of students' export? Second, the increase in the number of people receiving higher education will inevitably lead to changes in the structure of the labor force. Does the existing level of the labor market match the level of the labor force trained by universities? How to deal with this contradiction? Three, how should we change some traditional models to find new breakthroughs in talent training for newly established universities? The overall structure of China's higher education needs a new thinking, and the concept of subordinate needs a new interpretation. Our most concentrated, principal, direct and urgent problem is not only how to cultivate outstanding leaders or innovative talents in the political, economic, social, cultural and academic fields, but also the reform of the state key construction universities. What is more important is that those who undertake the main force of popularization, directly face the economy, society, management and service. A large number of local colleges and universities transformation and development issues.

\section{Historical Reference and Current Situation}

Western developed countries in the 1960s and 1980s have entered the stage of popularization of higher education, they have also experienced the confusion we face today and new value judgment, but also have some far-reaching reform. After World War II, France, Germany, the United States and other countries began to recuperate. With the arrival of the peak population, the development of the country and society is imperative.

A large number of construction talents, developed countries began to realize the importance of Vocational and technical personnel training.The Grenoble Conference held in France before the May Storm in 1968 focused on how to strengthen cooperation between universities and enterprises in order to solve the problem that only engineering schools in France maintain traditional cooperative relations with the economic and business communities, and universities have long regarded themselves as "purely academic palaces". The White Paper on Technical Education published in 1956 upgraded some technical institutes to advanced technical institutes in order to attract more high-quality freshmen and improve the training level of senior engineers and technical experts in Britain .

In October 1968, Germany adopted the Agreement on Unified Colleges of the States of the Federal Republic, which decided to establish a Fachhochschule (FH), now renamed the University of Applied Technology, on the basis of the existing secondary technical education, in order to upgrade the specifications of technical education for the cultivation of talents. Nowadays, German higher vocational colleges and universities of applied technology together constitute the German higher vocational and technical education system. In the mid-1990s, 80\% of all German employees received systematic higher education. Vocational education in Germany became the "secret weapon" of the country's development.

The United States implemented career education in the 1970s. The overall goal of livelihood 
education is to increase the relevance of schools to society and eliminate any discrimination between general and academic education and vocational education. The Burkins Vocational Applied Technology Education Act of 1990 proposed the integration of academic and vocational education, technical preparatory projects, and the establishment of a new mode of financial assistance according to the degree of economic development. Historically, American vocational education created the need for an industrial economy to evolve from an agricultural economy to mass production. After years of development, Germany has 249 universities of Applied Technology in 2001, accounting for 59\% of the total number of colleges and universities. The University of Applied Technology mainly trains applied senior talents. 2/3 of German electromechanical engineers, 2/3 of enterprise economists and 1/2 of computer engineers are graduates of Applied Technology University. In 2003, Finland passed the law, clarified the applied technology.

The position and mission of universities. Finnish universities of Applied Technology account for $45 \%$ of the total number of students in higher education, forming a dual pattern of common development and complementarity with ordinary universities.Because of the higher demand for talents, western countries have strengthened the construction of Higher Vocational education, and even upgraded the level of vocational education to the undergraduate level equivalent to our country. In the 20th century, the western countries carried out unprecedented reforms in universities. Before that, the reforms of universities had expanded the functions of universities, increased the number of educated groups, and expanded the scale of universities. Now higher education can play an important role in China in a new form.

\section{Values and Development View}

There is no doubt that applied technology university belongs to undergraduate education in the field of higher education. Higher education is responsible for studying "profound knowledge" since its emergence. Burton Clark once analyzed that a firm establishment of the legitimacy of universities in modern society requires a broader perspective, establishing the following three foundations: The pursuit of knowledge, which includes profound knowledge and universal knowledge, based on the ultimate goal of human beings. social needs. Universities must always give society something to meet the needs of society. But what universities offer is not just what society wants, but more importantly what society needs. moral constraints. In the relationship between knowledge and morality, modern universities only attach importance to knowledge rather than morality, which is not conducive to the abuse of knowledge and rationality and the obedience to moral consciousness.Clark's remarks have long been a relief to us, and we should take into account that knowledge, society and morality are all factors that we can not ignore when we build our own university of applied technology.

\subsection{International Education Standards Should Be Considered in the Construction}

Applied technology university belongs to applied professional education. UNESCO adopted the International Classification of Educational Standards in 1975 in accordance with the educational plan and the types of personnel training, and revised the International Classification of Educational Standards in 1997. The classification divides elementary education into higher education into three levels.

In May 1993, the Federation of Austria passed the Applied Technology University Academic Study Act and established nine Applied Technology Universities. Austria has put the University of Applied Technology on a high standard since the beginning of the system design, paying attention to the training of scientific theory and practical technology, and the quality of graduates'employment has been improved. Therefore, the University of Applied Technology in 
Austria does not belong to the 5B category which emphasizes skills, but to the 5A category. In a sense, it also highlights the application of technology. The quality of university training.

"Technology" in the University of Applied Technology is a kind of "technology" in a broad sense. It is the name of "science, knowledge, engineering, technology, art" and other applied sciences and techniques. Specifically speaking, the knowledge granted by applied technology universities in China should be higher than that of colleges and universities, and it should be parallel to the general education at undergraduate level. Therefore, it is necessary to grant "universal knowledge" properly. The path of construction should be distinguished from vocational and technical education, and should not be included in the vocational education system, but should be included in the application. Professional education.

\subsection{The Classification Development of Higher Education Conforms to the Trend of China's Economic Development}

China is a middle-income developing country, after 30 years of reform and opening up, is in need of professional and technical personnel and high-level technical personnel stage, and at this stage is just the lack of such personnel. Developed countries have carried out a series of reforms without hesitation according to the needs of social and economic development. From the beginning of attaching importance to secondary vocational education to higher vocational education, many countries have listed applied technology universities as an independent system, awarding independent degrees and gradually getting rid of the shackles of vocational education system. At the same time, it is different from the general education system. It improves the status of Applied Technology Education and becomes an indispensable force for social and economic development. Although China and Western countries have different national conditions and different situations, it is the same choice that our country and Western countries faced at that time to adapt to the development of society, cultivate talents needed by society, promote economic level and social development through a new education system.

\subsection{The Construction of Applied Technology University Should follow the Development Rule of Higher Education}

In the 1960s and 1970s, the industrialization of Western European developed countries entered the middle stage. Some countries set up applied technology universities with the main objective of training high-level technical talents in accordance with the demand of economic development for the level and specifications of talents. In the relationship between education and social development, the development of education needs to be faster than social development. Mr. Pan Maoyuan once said, "Because it takes time to train talents, you can not wait for economic development to develop education, but should see the trend of development, prepare talents in advance."Developed countries attach great importance to the construction of University of applied technology, whether it is the increase of high-level technical personnel or the development and utilization of high-tech, have a greater support for social development. Some western developed countries, such as Sweden, Finland and other countries have significantly enhanced their real economy. In 2007 Finland was named "the most competitive country in the EU" by the European Union think tank Lisbon Commission. The University of applied technology is the University first, and the university should maintain its original spiritual essence. It should follow the objective law of the development of higher education, follow the internal and external laws of higher education, cater to the development of society, but also adhere to the nature of the university. 


\section{The Construction of Applied Technology Universities Should Avoid Pragmatism}

Although the attributes, functions and categories of undergraduates are changing and developing , the knowledge it imparts is no longer confined to the metaphysical knowledge system, and the knowledge and skills required by various societies are introduced into colleges and universities, we should distinguish pragmatism from pragmatism so as to avoid the spread of pragmatism in Colleges and universities. Applied professional education can not be equated with vocational skills training. Professor Liu Zhentian of Renmin University pointed out that in the process of transformation, newly-built undergraduate colleges and universities often emphasize the seamless connection between talent cultivation and market demand, the realization of zero-distance with industrial demand, and the seamless connection and zero-distance emphasize the directness and usefulness of theory to solve practical production and life problems, essentially canceling rationality fundamentally. On the other hand, it is a pragmatic pragmatism, which is active, learning, using and learning. The unity and diversity, permanence and variability of undergraduate education should be organically combined. The knowledge we teach is not what society wants, but what society needs. We should not only consider the temporary needs of talents, but also consider the long-term development of individuals. This is in line with the nature of education.

The establishment of Applied Technology University is not a formal establishment. It is the establishment of a concept. Applied Technology University will have an interlaced but selfcontained path with general education in the future development. This has long been unknown in foreign countries, many western countries have now built a bridge between general education and applied education, and applied education to a new level. In 2005, Finland amended the law and the University of Applied Technology was granted the right to grant master's degrees, thus upgrading vocational and technical education in Finland to the level of master's degree education . At the undergraduate level of the future higher education in our country, students can have two choices: one way is ordinary undergraduate course - General master - doctor, the other way is applied undergraduate course - applied master - doctor, students can choose to study general master or applied master after graduation from university, the master can be followed after graduation. Continue to pursue a doctorate in a more professional field.

\section{Conclusion}

The value construction of Applied Technology University is not a simple infusion of fragmentary values, nor a simple copy of the above concepts and values. It is different from traditional universities, but also rooted in traditional universities. As far as China is concerned, it is a new thing and needs to be explored constantly in its development, so its value system is dynamic. However, the University of Applied Technology belongs to the category of higher education, no matter how it develops, it should always have the essential attribute of higher education, in line with the law of education, in addition, it needs to be constantly improved to adapt to the development of society.

\section{References}

[1] Cheng Zhongmei, Xiao Xiaohua. Recruitment and Enlightenment of General Undergraduate Colleges and Universities from 1999 to 2008 [J] University (Academic Edition), 2010 (5).

[2] Liu Zhentian. Transformation and Development of Local Undergraduate Colleges and Universities and Epistemological and Methodological Requirements for Higher Education [J] China Higher Education Research, 2014 (6).

[3] He Guoqing, history of foreign higher education [M] Beijing: People's education press, 2006. 
[4] Wu Xueping. Research on International Vocational and technical education [M]. Hangzhou: Zhejiang University press, 2004.

[5] Cui Zheng Yun. The legislation and characteristics of American vocational education [J]. Education and occupation, 1996 (12).

[6] Jiang Da Yuan. Introduction to German universities. [J]. vocational and technical education in China, 2004 (20): 56- 58.

[7] Li Jianzhong. Characteristics and Experience of Finnish University of Applied Technology [J]. University (Academic Edition), 2014 (2).

[8] Editor-in-Chief, Burton Clark. New Theory of Higher Education - Multidisciplinary Research [M] Hangzhou: Zhejiang Education Publishing House, December 2001.

[9] Hole is sensitive. The way to build an applied university [M]. Beijing: Peking University press, 2006. Fifteenth pages.

[10] Pan Maoyuan. Theory and practice of training applied talents [M]. Xiamen: Xiamen University press, 2011:18.

[11] Zhang Zhi. Austria University of applied technology research and development [J]. University (Academic Edition), 2013 (9).

[12] Dong Liping. Local university transformation development and construction of Applied Technology University [J] education research, 2014 (8). 